\title{
POSTTRAUMATIC DENSITY OF THE BONE TISSUE OF THE RAT'S MANDIBLE WITHOUT PATHOLOGY, ON THE BACKGROUND OF NALBUPHINE INTAKE AND AFTER LINCOMYCIN TREATMENT
}

\author{
Assistant Professor Rostyslav Sohuyko, \\ Professor Zoryana Masna, \\ Assistant Professor Khrystyna Pavliv
}

Ukraine, Lviv, Danylo Halytsky Lviv National Medical University; Operative surgery with topographic anatomy; Head of the operative surgery and topographic anatomy department; Operative surgery with topographic anatomy

DOI: https://doi.org/10.31435/rsglobal_ws/30112019/6772

\begin{tabular}{|c|c|}
\hline ARTICLE INFO & ABSTRACT \\
\hline $\begin{array}{l}\text { Received: } 29 \text { September } 2019 \\
\text { Accepted: } 18 \text { November } 2019 \\
\text { Published: } 30 \text { November } 2019\end{array}$ & $\begin{array}{l}\text { Numerous dental manipulations are accompanied by bone injuries. Various } \\
\text { types of drug correction are widely used for correction and optimization of } \\
\text { bone tissue reconstruction after bone-traumatic injury. The evaluation of }\end{array}$ \\
\hline $\begin{array}{l}\text { KEYWORDS } \\
\text { bone tissue, } \\
\text { bone-traumatic injury, } \\
\text { density, nalbuphine, } \\
\text { opioid dependence, } \\
\text { lincomycin. }\end{array}$ & $\begin{array}{l}\text { methods which gives the possibility to evaluate and predict early } \\
\text { quantitative and qualitative changes in various pathological conditions, as } \\
\text { well as to trace their dynamics in clinical and experimental conditions. In } \\
\text { our research we have find out the peculiarities of the density dynamics of } \\
\text { the bone tissue of the mandible after causing bone-traumatic injury to } \\
\text { intact animals and animals that have been taking nalbuphine for a long } \\
\text { time, as well as after treatment with lincomycin. }\end{array}$ \\
\hline
\end{tabular}

Citation: Rostyslav Sohuyko, Zoryana Masna, Khrystyna Pavliv. (2019) Posttraumatic Density of the Bone Tissue of the Rat's Mandible without Pathology, on the Background of Nalbuphine Intake and After Lincomycin Treatment. World Science. 11(51), Vol.2. doi: 10.31435/rsglobal_ws/30112019/6772

Copyright: (C) 2019 Rostyslav Sohuyko, Zoryana Masna, Khrystyna Pavliv. This is an open-access article distributed under the terms of the Creative Commons Attribution License (CC BY). The use, distribution or reproduction in other forums is permitted, provided the original author(s) or licensor are credited and that the original publication in this journal is cited, in accordance with accepted academic practice. No use, distribution or reproduction is permitted which does not comply with these terms.

Introduction. Numerous dental manipulations, in particular tooth extraction, resection of the tooth root, implant placement, etc., are accompanied by bone injuries. The reason of the most common causes of patients' referral to the clinic of maxillofacial surgery include jaw injury with the break of bone integrity $[1,3,6,9,12]$. Data from numerous scientific studies indicate that there are many factors that affect the course of reparative osteogenesis - concomitant or background diseases, bad habits, patient's age, alcohol or drug dependence $[7,8,10,11,12,13,14,15,16]$. Various types of drug correction are widely used for correction and optimization of bone tissue reconstruction after bone-traumatic injury [13, $15,16,17,18]$. The evaluation of the course of reparative osteogenesis becomes possible with the x-ray methods usage, in particular - dental radiovisiography, which has become widely used in modern dentistry [4]. This method allows not only to find out the quality of bone tissue, but also to evaluate and predict early quantitative and qualitative changes in various pathological conditions, as well as trace their dynamics in clinical and experimental conditions [4, 7, 14,].

Purpose of our study: to find out the peculiarities of the density dynamics of the bone tissue of the mandible after causing bone-traumatic injury to intact animals and animals that have been taking nalbuphin for a long time, as well as after treatment with lincomycin.

Material and methods. The study was performed on 80 sexually mature, non-breeding male rats with a body weight of 180-200 g and 3.5 months old. Experimental animals were kept in the 
vivarium of the Danylo Halytsky Lviv National Medical University. All studies were conducted in accordance with the provisions of the European Convention for the protection of vertebrate animals used for experimental and other scientific purposes (Strasbourg, 1986), Council Directive 86/609/ EEC (1986), Law of Ukraine No. 3447-IV "On the Protection of Animals from Cruel handling".

All experimental animals were divided into 6 groups:

- Group 1 - intact animals that had bone-traumatic injury (15 animals);

- Group 2 - animals with the modeled opioid dependence (15 animals);

- Group 3 - animals with opioid dependence and with the bone-traumatic injury (15 animals);

- Group 4 - animals that were treated with lincomycin after a bone-traumatic injury (15 animals);

- Group 5 - animals with opioid dependence, which were treated with lincomycin (15 animals) after bone-traumatic injury;

- Group 6 - control (5 animals).

The injury was modeled by breaking the integrity of the bone tissue of the mandible in the area of molars with the help of dental drill. The operation was performed under thiopental anesthesia [5].

Opioid dependence was modeled by the administration of a narcotic analgetic Nalbuphine on a daily basis (once a day at the same time interval). Nalbuphine was administered intramuscularly according to the following schedule: 1 week $-8 \mathrm{mg} / \mathrm{kg}$, 2nd week $-15 \mathrm{mg} / \mathrm{kg}$, 3rd week - $20 \mathrm{mg} /$ $\mathrm{kg}, 4$ th week - $25 \mathrm{mg} / \mathrm{kg}, 5$-this week $-30 \mathrm{mg} / \mathrm{kg}$, 6th week - $35 \mathrm{mg} / \mathrm{kg}$ [2].

Lincomycin (30\% solution) was administered intraperitoneally at a dosage of $25 \mathrm{mg} / \mathrm{kg}$ once a day for 6 days after bone injury.

Control of the quality of bone tissue of the mandible in the area of injury was carried out using a dental radiovisiographer Siemens with the software Trophy Radiology. The unit of measurement of tissue density was taken the conventional unit of gravity (CUG).

Investigations of the quality of bone tissue of the mandible were performed weekly to all animals of all experimental and control groups.

For each group, the arithmetic mean value of the researched indicator, the variance and the confidence interval at the level of reliability of $\mathrm{P}=95 \%$ were determined.

Research results. An analysis of the density of the bone tissue of the rat's mandible within three weeks after performing bone-traumatic injury to intact animals made it possible to determine the presence of an expressed dynamics of the investigated index (Table 1).

Table 1. Dynamics of indices of bone tissue density of rat's mandible after bone injury.

\begin{tabular}{|l|l|l|l|l|l|}
\hline & M & Dysp & $\Delta$ & M- $\Delta$ & M+ $\Delta$ \\
\hline control & 75,33 & 177,87 & 14 & 61,34 & 89,33 \\
\hline 1 week after trauma & 107,67 & 689,87 & 27,56 & 80,1 & 135,23 \\
\hline 2 week after trauma & 152 & 394,8 & 20,85 & 131,15 & 172,85 \\
\hline 3 week after trauma & 99,5 & 820,7 & 30,06 & 69,44 & 129,56 \\
\hline
\end{tabular}

The obtained data indicate that, after two weeks after injuries, the density of the mandibular bone tissue in the traumatized area gradually increases and by the end of the second week doubles in comparison with the norm. During the third week after the injury, the investigated index is reduced, but remains slightly higher than in intact animals.

Dynamics of density of bone tissue of the mandible of the rat after bone destruction with the subsequent treatment with lincomycin is similar - the observed index increases within two weeks after the injury and decreases to the end of the third, but its absolute values are much lower than in animals not treated with lincomycin (Table 2).

Table 2. Dynamics of indicators of density of bone tissue of rat's mandible after bone injuries with subsequent correction by lincomycin

\begin{tabular}{|l|l|l|l|l|l|}
\hline & M & Dysp & $\Delta$ & M- $\Delta$ & M+ \\
\hline control & 75,33 & 177,87 & 14,00 & 61,34 & 89,33 \\
\hline 1 week after trauma & 92,33 & 739,87 & 28,55 & 63,79 & 120,88 \\
\hline 2 week after trauma & 104,00 & 722,80 & 28,21 & 75,79 & 132,21 \\
\hline 3 week after trauma & 95,17 & 1326,97 & 38,23 & 56,94 & 133,40 \\
\hline
\end{tabular}

To reveal the peculiarities of changes in the quality of bone tissue of the mandible on the background of prolonged nalbuphine intake, we analyzed the dynamics of this indicator for 6 weeks of dosing (Table 3). 
The analysis of the obtained data showed that after two weeks of nalbuphine intake, the studied index gradually increases, and during the third week it decreases practically to norm. During the fourth and fifth weeks the bone density increases again, and in the sixth week it decreases and only slightly exceeds the norm (Table 3 ).

Table 3. Dynamics of density indices of bone tissue of the rat's mandible on the background of the nalbuphine intake

\begin{tabular}{|l|l|l|l|l|l|}
\hline & $\mathrm{M}$ & Dysp & $\Delta$ & $\mathrm{M}-\Delta$ & $\mathrm{M}+\Delta$ \\
\hline Intact animal & 75,33 & 177,87 & 14 & 61,34 & 89,33 \\
\hline $1^{\text {st }}$ week of the experiment & 78,17 & 191,77 & 14,53 & 63,63 & 92,7 \\
\hline $2^{\text {nd }}$ week of the experiment & 85,67 & 809,47 & 29,86 & 55,81 & 115,52 \\
\hline $3^{\text {rd }}$ week of the experiment & 75,5 & 333,1 & 19,15 & 56,35 & 94,65 \\
\hline $4^{\text {th }}$ week of the experiment & 82,33 & 433,07 & 21,84 & 60,49 & 104,17 \\
\hline $5^{\text {th }}$ week of the experiment & 83,17 & 380,97 & 20,48 & 62,68 & 103,65 \\
\hline $6^{\text {th }}$ week of the experiment & 79,5 & 537,5 & 24,33 & 55,17 & 103,83 \\
\hline
\end{tabular}

Since the bone density of the mandible after three weeks of nalbuphine intake is as close as possible to normal values, this term was chosen for causing a bone-destroying trauma to animals with nalbuphine dependence. The obtained data suggest that the dynamics of bone density after bonetraumatic injury with the use of nalbuphine is quite different from that of intact animals. One week after the trauma, the investigated index practically does not change, after two weeks it increases somewhat and its extension continues until the end of the experiment - after 3 weeks after injury, the density of bone tissue with the use of nalbuphine is almost twice as high as in intact animals (Table 4).

Table 4. Dynamics of the bone tissue density indices of the rat's mandible after a bonetraumatic injury on the background of the nalbuphine intake

\begin{tabular}{|l|l|l|l|l|l|}
\hline & M & Dysp & $\Delta$ & M- $\Delta$ & M $+\Delta$ \\
\hline control & 75,33 & 177,87 & 14 & 61,34 & 89,33 \\
\hline 3 week of the nalbuphine intake / before trauma & 75,5 & 333,1 & 19,15 & 56,35 & 94,65 \\
\hline $\begin{array}{l}4 \text { week of the nalbuphine intake / 1 week after } \\
\text { trauma }\end{array}$ & 74,5 & 421,1 & 21,54 & 52,96 & 96,04 \\
\hline $\begin{array}{l}5 \text { week of the nalbuphine intake / 2 week after } \\
\text { trauma }\end{array}$ & 86 & 1128,4 & 35,25 & 50,75 & 121,25 \\
\hline $\begin{array}{l}\text { 6 week of the nalbuphine intake / 3 week after } \\
\text { trauma }\end{array}$ & 133,5 & 3108,3 & 58,51 & 74,99 & 192,01 \\
\hline
\end{tabular}

The study of the lincomycin influence on the condition of the bone tissue of the rat's mandible after the bone-traumatic injury conducted on the background of prolonged nalbuphine intake, made it possible to establish that, after a traumatic injury, the density of bone tissue drastically increases and gradually decreases over the next two weeks, only slightly exceeding the norm at the end of the experiment (Table 5).

Table 5. Dynamics of bone tissue density indices of the rat's mandible after the bone injury on the background of the nalbuphine intake with the following lincomycin correction

\begin{tabular}{|l|l|l|l|l|l|}
\hline & $\mathrm{M}$ & Dysp & $\Delta$ & $\mathrm{M}-\Delta$ & $\mathrm{M}+\Delta$ \\
\hline control & 75,33 & 177,87 & 14,00 & 61,34 & 89,33 \\
\hline 3 week of the nalbuphine intake / before trauma & 75,5 & 333,1 & 19,15 & 56,35 & 94,65 \\
\hline 4 week of the nalbuphine intake / 1 week after trauma & 112,33 & 3299,87 & 60,28 & 52,05 & 172,62 \\
\hline 5 week of the nalbuphine intake / 2 week after trauma & 91,67 & 401,47 & 21,03 & 70,64 & 112,69 \\
\hline 6 week of the nalbuphine intake / 3 week after trauma & 86,17 & 496,57 & 23,39 & 62,78 & 109,55 \\
\hline
\end{tabular}

Comparison of the dynamics of bone density of the rat's mandible three weeks after bone-traumatic injury in animals of different experimental groups showed that in animals without background pathology the dynamics of the studied index was similar to both in the treatment of lincomycin and without its use the maximum value of bone density reached through two weeks after the injury and decreased during the third week (Fig. 1). However, the absolute values of the studied index for all three weeks after the injury were significantly lower in animals treated with lincomycin (Fig. 1). 
Animals with background opioid dependence had quite different dynamics of density of bone tissue after injury in the groups where the treatment was conducted with lincomycin and where it was not used. In animals that had not been treated with lincomycin after injury, but continued nalbuphine intake, bone density declined slightly during the first week after injury, increased somewhat during the second week and increased rapidly during the third week. In animals treated with lincomycin, the dynamics of the studied index was quite different - bone density increased significantly during the first week and gradually decreased to the third (Fig. 1).

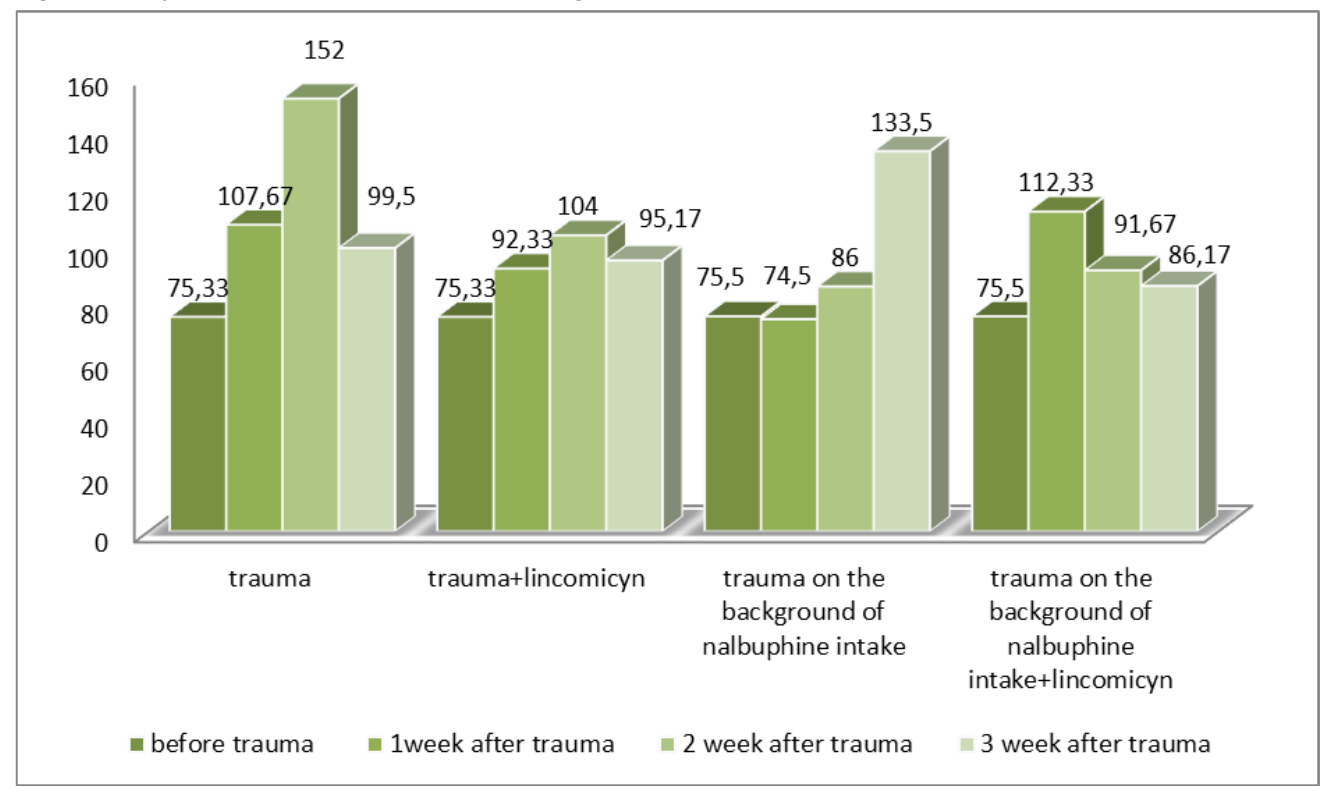

Fig. 1. Dynamics of density of bone tissue of rat's mandible during three weeks after bone-traumatic injury in animals of different experimental groups.

An analysis of bone density indices after bone-traumatic injury to animals of different experimental groups at different periods of the experiment shows that during the first week after the injury, the biggest difference from the norm was registered in the group of animals which were treated with lincomycin on the background of nalbuphine use; during the second week - intact injured animals; during the third week animals that were injured on the background of nalbuphine use without correction by lincomycin (Fig. 2).

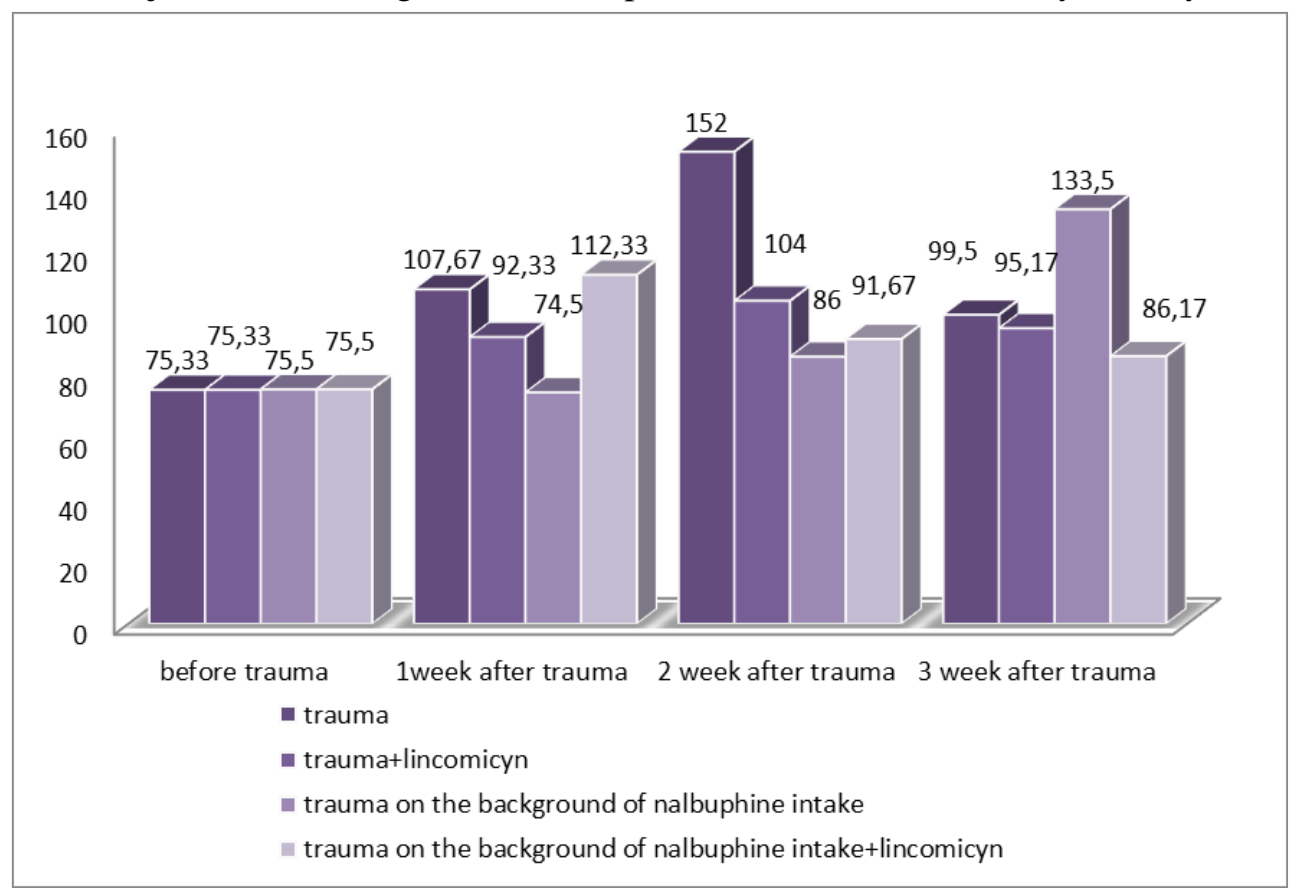

Fig. 2. Comparison of the indices of bone density of rat mandible in animals of different experimental groups within three weeks after a bone-traumatic injury. 
Throughout the experiment, the density of bone tissue after injury was higher than in norm in all experimental groups, with the exception of animals with nalbuphine addiction without correction of lincomycin one week after injury.

\section{Conclusions.}

1. The application of a bone-traumatic injury leads to an expressed dynamics of bone density of bone tissue and the area of injury, which indicates a change in its quality.

2. Dynamics of density of bone tissue of the mandible after bone-traumatic injury in intact animals, animals with the nalbuphine addiction and animals with the treatment of lincomycin, is different.

3. Three weeks after bone-traumatic injury, the bone density in opioid-dependent animals, which had not been treated with lincomycin, exceeded the norm by half; in animals of other experimental groups, the test indicator was only slightly higher than normal.

4. For persons who have been using nalbuphine for a long time or having opioid dependence, after treatment of bone loss, it is necessary to treat with lincomycin, since the absence of such treatment leads to significant changes in the density of the bone tissue, and hence its quality.

\section{REFERENCES}

1. Аветіков Д.С., Локес К.П., Ставицький С.О., Яценко І.В., Розколупа О.О.. Переломи нижньої щелепи: аналіз частоти виникнення, локалізації та ускладнень. Вісник проблем біології і медицини. 2014;3(3):62-64.

2. Онисько Р.М., Пальтов С.В., Фік В.Б., Вільхова І.В., Кривко Ю.Я., Якимів Н.Я., винахідники; Львівський національний медичний університет імені Данила Галицького, патентовласник. Спосіб моделювання фізичної опіоїдної залежності у щурів. Патент України № 76564. 2013 Січ 10.

3. Рибачук А.В., Мамонов Р.О., Маланчук В.О. Епідеміологія травматичних переломів нижньої щелепи в період з 2005 по 2014 р. за матеріалами клініки кафедри. Харківська хірургічна школа. 2016;1:117-122.

4. Рижук Х, Кухлевський Ю, Масна 3. Особливості щільності твердих тканин зубощелепного апарату у осіб юнацького віку, що проживають на Львівщині. Вісник проблем біології і медицини. 2011;3(1):138-140.

5. Согуйко Р.P., Масна 3.3., Билинь Г.В., винахідники; Львівський національний медичний університет імені Данила Галицького, патентовласник. Спосіб моделювання травми нижньої щелепи щура. Патент на корисну модель №118784. 2017 Серп 28

6. Федірко Г.В. Сучасне уявлення про механізм регенерації нижньої щелепи в умовах політравми. Клінічна стоматологія. 2015;1:89-94.

7. Carmo JZB, Medeiros SF. Mandibular Inferior Cortex Erosion on Dental Panoramic Radiograph as a Sign of Low Bone Mineral Density in Postmenopausal Women. Rev Bras Ginecol Obstet. 2017;39(12):663-669. doi: 10.1055/s-0037-1606622.

8. Ferguson BL, Lieblich SE, Dodson TB. Third Molar Extraction and Persistent Use of Opioids. JAMA. 2018;320(22):2377. doi: 10.1001/jama.2018.17187.

9. Huang D, Wu Q, Zhou X, Kang F. Activity and morphologic changes in the mandible after mandibular osteotomy. Am J Orthod Dentofacial Orthop. 2019;155(1):40-47. doi: 10.1016/j.ajodo.2018.02.016.

10. Iero PT, Mulherin DR, Jensen O, Berry T, Danesi H, Razook SJ. A Prospective, Randomized, Open-Label Study Comparing an Opioid-Sparing Postsurgical Pain Management Protocol with and Without Liposomal Bupivacaine for Full-Arch Implant Surgery. Int J Oral Maxillofac Implants. 2018;33(5):1155-1164. doi: 10.11607/jomi.5938.

11. Kim JW, Tatad JCI, Landayan MEA, Kim SJ, Kim MR. Animal model for medication-related osteonecrosis of the jaw with precedent metabolic bone disease. Bone. 2015;81:442-448. doi: 10.1016/j.bone.2015.08.012.

12. Kim TG, Chung KJ, Lee JH, Kim YH, Lee JH. Clinical Outcomes Between Atrophic and Nonatrophic Mandibular Fracture in Elderly Patients. J Craniofac Surg. 2018;29(8):e815-e818. doi: 10.1097/SCS.0000000000004863.

13. Mingzhe L, Xiaofeng X, Bing X. Current therapy of atrophic edentulous mandibular fractures among elderly people. Hua Xi Kou Qiang Yi Xue Za Zhi. 2017;35(4):433-436. doi: 10.7518/hxkq.2017.04.017.

14. On SW, Kim HJ, Kim J, Choi JW, Jung YW, Song SI. Effect of Osteoporosis on Bone Density of Orthognathic Osteotomy Sites in Maxillofacial Region. J Craniofac Surg. 2016;27(7):e678-e683.

15. Pichardo SEC, Ten Broek FW, Richard van Merkesteyn JP. Treatment of pathologic fractures of the mandible in stage III medication-related osteonecrosis of the jaw-an observational study. J Craniomaxillofac Surg. 2018;46(8):1241-1246. doi: 10.1016/j.jcms.2018.05.025.

16. Poghosyan YM, Hakobyan KA, Poghosyan AY, Avetisyan EK. Surgical treatment of jaw osteonecrosis in «Krokodil» drug addicted patients. J Craniomaxillofac Surg. 2014;42(8):1639-1643. doi: 10.1016/j.jcms.2014.05.005.

17. Yoshioka Y, Yamachika E, Nakanishi M, Ninomiya T, Nakatsuji K, Kobayashi Y, et al. Cathepsin K inhibitor causes changes in crystallinity and crystal structure of newly-formed mandibular bone in rats. Br J Oral Maxillofac Surg. 2018;56(8):732-738. doi: 10.1016/j.bjoms.2018.08.003.

18. Yoshioka Y, Yamachika E, Nakanishi M, Ninomiya T, Nakatsuji K, Matsubara M, et al. Molecular alterations of newly formed mandibular bone caused by zoledronate. Int J Oral Maxillofac Surg. 2018;47(9):1206-1213. doi: 10.1016/j.ijom.2018.02.002. 